\title{
Institutional Repositories of Open Access: A paradigm of innovation and changing in Educational Politics
}

\author{
Nikos KOUTRAS, Maria BOTTIS* \\ Msc, Ionian University, Department of Archives and Library Science, 49100, Corfu, Greece \\ Ass. Professor, School of Information Science and Informatics, Department of Archive, Library Science and Museology, Ionian University, \\ 49100, Corfu, Greece
}

\begin{abstract}
In the Lisbon Summit (2000), the European Commission adopted the triangle of knowledge (education, research, innovation). These three concepts are fundamental "ingredients" of the European educational policy. In today's societies, education is the tool leading to research and then, to innovation. Thus, institutional repositories play a key role here. They represent a major and an alternative gate of knowledge. In conclusion, this paper will examine relevant and current initiatives (open access initiatives) and policies among European countries.
\end{abstract}

(C) 2013 The Authors. Published by Elsevier Ltd. Open access under CC BY-NC-ND license.

Selection and peer-review under responsibility of The Association of Science, Education and Technology-TASET, Sakarya Universitesi, Turkey.

Keywords: institutional repositories; information society; open access; research; innovation; educational politics

\section{Introduction}

At both the European level, within initiatives, programs, decisions, directives, recommendations, cooperation and partnerships, and the international level, there is a steady increase of interest in the development of open access repositories (Koutras, 2012). There is today no doubt that information, theoretically and practically, should always be open and accessible to as many users as possible.

The European Union, a loyal host of the Information Society, is keen to implement educational politics that will assist to overcome current and forthcoming obstacles as regards means of entry. Information ought to be reached conveniently. Access should not be restrained by unjust legal rules nor bureaucracy. Therefore,

*Tel.: +30 6948 309830; fax: +30 26610 21125, tel. 306932 109020, fax: 30266103116.

E-mail address: koutras@ionio.gr, botti@otenet.gr. 
institutional open access repositories come to play a crucial role in offering open access publications to researchers, scientists etc.

However, the current controversy as regards Institutional Repositories is characterized by an unbalanced mixture of technology push, a discussion on the level of academic autarchy and the debate on the role of (commercial) publishers (Kircz, 2005).

\section{Historical overview and definitions}

\subsection{Open access as a term}

The term 'learning object' (a collection of content items, practice items and assessment items, combined, based on a single learning objective, providing smaller, reusable units of learning) originates from Wayne Hodgins in 1994. It rapidly became one of the important aspects of higher education and scientific research. The full concept of a 'learning object', though, was first described by Gerard in 1976 (Polsani, 2003). Learning object repositories are similar to digital libraries, and enable the sharing and managing of educational resources, in an open content model (like the Orange Grove, Florida's digital repository for instructional resources, such as open textbooks). A main feature of Open Educational Resources (OERs) is the dissemination of the idea that information may be designed and promoted in such way it may be easily re-used within various educational forms (Makridou, Araka and Koutras, 2011).

In 1998, David Wiley coined the term 'open content' by analogy with open source. 'Open content' targeted the educational community, but the term quickly entered the vernacular of internet users. One role of the open content in the history of OERs is the popularization of the idea that the principles of the open source can be productively applied also to content. Hence, the creation of the first widely adopted open license for content (Open Publication License).

Indeed, open access can be defined as the practice of providing online access to scientific content that is free to charge to the reader. In the context of research and development, open access typically focuses on access to 'scientific information', which refers to two critical categories:

- Peer-reviewed scientific research articles (published in academic journals);

- Scientific research data (data underlying publications and/ or raw data)

It is imperative to stress that:

- Open access publications follow the same peer review process as non-open access publications;

- As an open access requirement comes after the initial decision to publish, there is no obligation to publish anything as open access: it depends upon the researchers whether they want to publish their work or not under open access;

- As the decision on whether to commercially exploit research outputs (for instance through patents or otherwise) is made after the decision to publish (open access or not), open access does not interfere with the commercial exploitation of research results.

\subsection{Open access models}

There are two open access models:

- 'Green' (self-archiving) open access means that the published article or the final peer-reviewed manuscript is archived by the researcher in an online repository before, after or alongside its publication. Access to this 
article is often delayed ('embargo period'). Publishers recoup their investment by selling subscriptions and charging pay-per-download/view fees during this period during an exclusively period. This model is promoted alongside the 'Gold' route by the open access community of researchers and librarians, and is often preferred.

- 'Gold' open access (open access publishing or the author pays for publishing costs) means that a publication is immediately provided in an open access mode by the scientific publisher. Associate costs shift from users to the university or the research institute to which the researcher is affiliated, or to the funding agency supporting the research. This model if usually the one promoted by the community of well-established scientific publishers in the business.

Most well-established publishers have adapted to the research community's interest in publishing in open access mode, yet usually in favor of 'Gold' open access. Nevertheless, a large number of journals, including those with high prestige and/or high impact factors have also developed self-archiving policies ('Green' open access) that are compatible with the policies of research funding bodies such as the Commission for Horizon 2020 .

\section{Institutional repositories nowadays-their significance}

The initial point of the usual debates on institutional repositories is the assignment of the universities and other institutions of higher education and/ or scientific research. In particular, the center of the discussion is scientific research and education, as well as the kinds of communication regarding these activities via the institutions and towards society at large.

The organization, the management and the operation of an institutional repository consists on a complex set of actions which contains various initiatives such as: data collection and digitization, appropriate forms and subject matter of archives, adherence to a legislative framework on intellectual property and correct determination of rules and standards on scholarly communication, metadata and development of repository infrastructure (Barton and Waters, 2004). Institutional repositories should aim at specific targets in order to work efficiently.

Therefore, institutional repositories, as an innovative model of knowledge dissemination, reform the whole educational framework on research methods, information management and education alike. Under these circumstances, it is necessary to keep a rational eye on all processes, stakeholders and governmental decisions about educational politics. Definitely, effective interaction is a crucial as regards education politics with great efficiency.

To sum up, an institutional repository is an online resource for the storing (in digital form) of academic materials, such as theses, dissertations and research articles, in the setting of a university or other institution. The institutional repositories' history, starting from the early 1990s, is a relatively short one. The average 'age' of a repository in 2010 is about six years. Such materials, which would once only have existed in print format, and secreted in basements and other more primitive storage facilities, are scientific, technological, artistic, cultural or historical and other.

\subsection{Education and open access initiatives}

The movement of open educational resources is rising in the higher education environment. Throughout the world there are presently more than 2.500 open access courses (opencoursewares) from over 200 universities (Wiley, 2007).

- In the United States 1.700 courses have been made available by seven university-based projects (http://ocw.mit.edu, http://cnx.rice.edu, http://ocw.jhsph.edu, http://ocw.tufts.edu, http://www.cmu.edu/oil, http:ocw.nd.edu, http://ocw.usu.edu).

- In China, 451 courses are offered to 176 university members of the China Open Resources for Education (CORE) consortium (http:www.core.org.cn/cn/jpkc/index_en.html). 
- In Japan, 350 courses are offered by ten universities participating in the Japanese OCW Consortium (http://www.jocw.jp).

- In France, 178 courses are offered by eleven universities, members of the ParisTech OCW project http://graduateschool.paristech.org).

There is a vast amount of educational resource projects underway with targeted external funding in support of their realization. Particularly, the William and Flora Hewlett Foundation has put millions of dollars into university-based open educational resource projects around the world.

\subsection{European perspectives on institutional repositories of open access}

There is constant rise of scientific information and its' use in the European Union (Koutras, 2010).

A communication issued on $14^{\text {th }}$ February 2007, regulates access, dissemination and preservation of scientific information among European Union members. Thus, open access institutional repositories can be used as an alternative means in relation to additions and changes regarding the European educational framework.

Access, dissemination and preservation of information have acquired intense attention among member-states of the European Union. The outcome of this focus is the creation of a specific operational framework which would include the crucial parameters described above.

In recent years, rising subscription prices for scientific journals have put a strain on university library budgets and research institutions. Businesses also experience problems in accessing scientific information. According to a 2009 UK survey, a significant share of Small and Medium sized Enterprises (SMEs) (55\%) said that they had recently experienced difficulty accessing a research article (against 34\% in the case of large companies), with the cost reported as the key difficulty (Publishing Research Consortium, 2009).

Two recent European Commissions public consultations show that researchers, libraries, research funders and businesses believe that there is a problem with access to scientific information and that this is a major barrier to the optimal circulation of knowledge in Europe, affecting both academic research and industrial intake of research results. Respondents to these consultations indicate that open access is a very important tool to overcome access limitations (European Commission, 2012). Over 90\% of respondents expressed the view that publications resulting from publicly funded research should, as a matter of principle, be available in open access mode.

Open access is backed by a growing number of universities, research centers and funding agencies in Germany, UK, the Nordic countries and all across Europe as well as beyond. National initiatives and practices are still fragmented, thus preventing the European Union from realizing its full research and innovation potential.

\section{Conclusion}

There are no national policies encouraging institutions to maintain publicly accessible websites gathering information concerning their admissions policies, available facilities and services.

Open access educational resources offered by institutional repositories become an alternative service of education. This invaluable service needs to be founded upon an effective equilibrium between copyright law and open access. It can also be seen as another way realizing the potential of the Lisbon Strategy and its 'triangle' of knowledge: education-research-innovation.

To sum up, institutional repositories offer an innovative platform of education and research. Education combined with research leads to innovation-this is the triangle of knowledge we need to have in mind. Therefore, there should be adequate and constant interaction between information scientists who are responsible for the services of the institutional repositories, and scholars or end-users, interested in collecting and studying further informational resources. 


\section{References}

Antelman, K. (2004) Do Open-Access Articles Have a Greater Research Impact? College \& Research Libraries. $65(5), 372-382$.

Barwick, J. (2007) Building an institutional repository at Loughborough University: some experiences. Program: electronic library and information systems. [Online] 41 (2), 113-123.

Bodard, G. \& Mahony, S. (2010) Digital Research in the Study of Classical Antiquity. Ashgate Publishing, Ltd. Chen, K. \& Hsiang, J. (2009) The unique approach to institutional repository: Practice of National Taiwan University. Electronic Library, The. [Online] 27 (2), 204-221.

Chousos, N. et al. (2009) 'Development of open access repositories: Issues and solutions', in 5 November 2009 [online]. Available from: http://eprints.rclis.org/14795/ (Accessed 11 June 2013). In Greek.

European Commission (2011) Communication from the Commission to the European Parliament, the Council, the European Economic and Social Committee and the Committee of the Regions: Horizon 2020-The EU framework Programme for Research and Innovation 2014-2020. [online]. Available from: http://eurlex.europa.eu/LexUriServ/LexUriServ.do?uri=COM:2011:0808:FIN:en:PDF. [online]. Available from: http://eur-lex.europa.eu/LexUriServ/LexUriServ.do?uri=COM:2011:0808:FIN:en:PDF.

European Commission (2012) Online survey on scientific information in the digital age. Studies and reports. Brussels: Publications Office of the European Union. [online]. Available from:

http://ec.europa.eu/research/science-society/document_library/pdf_06/survey-on-scientific-information-digitalage en.pdf(Accessed 11 June 2013).

Genoni, P. (2004) Content in institutional repositories: a collection management issue. Library Management. [Online] 25 (6/7), 300-306.

Gerard, R. (1967) 'Shaping the mind: Computers in education', in in Applied Science and Technological Progress: A Report to the Committee on Science and Astronautics, U.S. House of Representatives. National Academies.

Halling, C. (n.d.) History of the Institutional Repository | eHow [online]. Available from:

http://www.ehow.com/about_6693254_history-institutional-repository.html (Accessed 13 June 2013).

Heinz-Dieter, M. \& Rowan, $\overline{\mathrm{B}}$. (2006) $\bar{N}$ ew Institutionalism in Education. SUNY Press.

Herb, U. \& Müller, M. (2008) The long and winding road: Institutional and disciplinary repository at Saarland University and State Library. OCLC Systems \& Services. [Online] 24 (1), 22-29.

Kircz, J. (2005) Institutional Repositories, a new platform in Higher Education and Research. Final version. [online]. Available from: http://igitur-archive.library.uu.nl/DARLIN/2005-0721-201648/UUindex.html (Accessed 6 June 2013).

Koohang, A. \& Harman, K. (2007) Learning Objects and Instructional Design. Informing Science.

Koutras, N., Araka I. \& Makridou E. (2011) 'Institutional Open Access Repositories in College Education: A proposal for their role in Open Educational Resources in Greece', in Alexandropoulou-Egyptiadou T., Bottis M. \& Iglezakis I. (eds.), Values and Freedoms in Modern Information Law and Ethics-Proceedings of the $4^{\text {th }}$ International conference on Information law and ethics 2011, Athens: Nomiki Bibliothiki,

Koutras, N. (2012) Educational Resources and Digital Repositories of Open Access. Athens: Nomiki Bibliothiki. Koutras, N. (2011) 'Open Access Repositories', in Bottis M. (ed.), An Information Law for the 21 st Century, Proceedings of the $3^{\text {rd }}$ International Seminar on Information Law and Ethics, Athens: Nomiki Bibliothiki. pp. 453-468.

Leach, A. (2013) EU Opens Up Access to Scientific Research. [online]. Available from:

$\mathrm{http} / / / \mathrm{b} \operatorname{logs} . w s j . c o m / t e c h-e u r o p e / 2013 / 03 / 19 /$ eu-opens-up-access-to-scientific-research/ (Accessed $11 \mathrm{June}$ 2013). [online]. Available from: http://blogs.wsj.com/tech-europe/2013/03/19/eu-opens-up-access-to-scientificresearch/ (Accessed 11 June 2013).

Lee, M. (2004) Global Trends, National Policies and Institutional Responses: Restructuring Higher Education in Malaysia. Educational Research for Policy and Practice. [Online] 3 (1), 31-46.

Makridou, E. et al. (2012) 'Open Educational Resources and Freedom of Teaching in College Education in Greece: Rivals or fellows?', in 2012 Ionian University, Corfu, Greece: Nomiki Vivliothiki. pp. 15-17. 
Mary R. Barton \& Margaret M.Waters (n.d.) Creating an Institutional Repository: LEADIRS Workbook. LEADIRS. USA: MIT Libraries. [online]. Available from: http://www.dspace.org/images/stories/leadirs.pdf (Accessed 11 June 2013).

Melgar, D. et al. (2013) Rapid modeling of the 2011 Mw 9.0 Tohoku-oki earthquake with seismogeodesy. Geophysical Research Letters. [Online] n/a-n/a.

Michael Day (2003) Prospects for institutional e-print repositories in the United Kingdom [online]. Available from: http://eprints-uk.rdn.ac.uk/project/docs/studies/impact/ (Accessed 6 June 2013).

Prosser, D. (2007) Repositories and Research Publications: Policies and Politics. [online]. Available from: http://eprints.ucl.ac.uk/3478/ (Accessed 6 June 2013). [online]. Available from: http://eprints.ucl.ac.uk/3478/ (Accessed 6 June 2013).

Publishing Research Consortium (2009) Access by UK small and medium-sized enterprises to professional and academic information. [online]. Available from:

http://www.publishingresearch.net/documents/SMEAccessResearchReport.pdf (Accessed 11 June 2013). p.52. [online]. Available from: http://www.publishingresearch.net/documents/SMEAccessResearchReport.pdf (Accessed 11 June 2013).

Shurville, S. et al. (2008) Educational and institutional flexibility of Australian educational software. CampusWide Information Systems. [Online] 25 (2), 74-84.

Swan, A. \& Brown, S. (2005) Open access self-archiving: An author study. [online]. Available from:

http://cogprints.org/4385/ (Accessed 6 June 2013). [online]. Available from: http://cogprints.org/4385/ (Accessed 6 June 2013).

Wiley, D. (2007) 'On the Sustainability of Open Educational Resource Initiatives in Higher Education', in Paper commissioned by the OECD's Centre for Educational Researh an Innovation (CERI) for the project on Open Educational Resources. 2007 OECD Publications. [online]. Available from: www.oecd.org/edu/oer (Accessed 7 June 2013).

Wiley, D. (2011) UPDATE: Introduction to Openness in Education, Winter 2012 [online]. Available from: http://opencontent.org/blog/archives/2080 (Accessed 7 June 2013).

Wiley David (2009) Symposium for teaching and learning with technology [online]. Available from: http://symposium.tlt.psu.edu/wiley/ (Accessed 10 June 2013).

Youdell, D. (2004) Engineering school markets, constituting schools and subjectivating students: the bureaucratic, institutional and classroom dimensions of educational triage. Journal of Education Policy. [Online] 19 (4), 407-431. 